\title{
Mediatización: hacia una ecología performática de los restos y la deriva
}

Sandra Valdettaro ${ }^{1}$

Recibido: 2015-08-09

Enviado a pares: 2015-08-09
Aprobado por pares: 2015-09-09

Aceptado: 2015-09-11

DOI: 10.5294/pacla.2015.18.4.8

\section{Para citar este artículo / To reference this article / Para citar este artigo}

Valdettaro, S. (Diciembre de 2015). Mediatización: hacia una ecología performática de los restos y la deriva. Palabra Clave, 18(4), 1137-1163. DOI: 10.5294/pacla.2015.18.4.8

\section{Resumen}

En el presente artículo se desarrolla una reflexión sobre la preeminencia de una ecología performativa en el ambiente actual de la mediatización, tomando en cuenta las modalidades de los lenguajes icónico-indiciales, las lógicas del contacto entre dispositivos, cuerpos y territorios, la deriva como experiencia, y la productividad de los restos.

\section{Palabras clave}

Mediatización, dispositivos, cuerpos, territorios, deriva, restos (Fuente: Tesauro de la Unesco).

1 Universidad Nacional de Rosario, Argentina. sandravaldettaro@gmail.com 


\section{Media Coverage: Towards a Performative Ecology of the Remains and Drift}

\section{Abstract}

In this article a reflection on the preeminence of a performative ecology in the current environment of the mediation is developed, taking into account the modalities of the iconic-indexical languages, logical contact between devices, bodies and territories, as experience drift and productivity remains.

\section{Keywords}

Media coverage, devices, bodies, territories, drift, remains (Source: Unesco Thesaurus). 


\section{Midiatização: rumo a uma ecologia performática dos restos e da deriva}

\section{Resumo}

No presente artigo, desenvolve-se uma reflexão sobre a preeminência de uma ecologia performática no ambiente atual da midiatização que considere as modalidades das linguagens icônico-indiciais, as lógicas do contato entre dispositivos, corpos e territórios, a deriva como experiência, e a produtividade dos restos.

\section{Palavras-chave}

Midiatização, dispositivos, corpos, territórios, deriva, restos (Fonte: Tesauro da Unesco). 


\section{Introducción}

Resulta ya un lugar común señalar la posición central que ha adquirido la vinculación entre dispositivos móviles informáticos, medios tradicionales y experiencia humana en el contexto actual de la mediatización. También se ha analizado frecuentemente la gramática de dicha vinculación, que produce una convergencia de lenguajes a partir de la digitalización y, paralelamente, una creciente divergencia en recepción, habilitando itinerarios de prácticas individuales y sociales cada vez más complejos. Desde por lo menos la caída del Muro de Berlín, asistimos a una nueva era marcada por cambios en los procesos productivos en el ámbito global, por nuevas formas del ejercicio político, por modificaciones profundas en la constitución del lazo público y por nuevas maneras de construir matrices subjetivas. Por ello, partimos de la constatación de una nueva modalidad de lazo social transmediática, intertextual, de serialidad y dispersión, en la cual las estrategias del contacto se solapan con apelaciones racionalísticas y críticas, en un soporte casi preeminente que es la pantalla.

Cualquier exploración, entonces, de las modalidades de dichas mutaciones socioculturales debe partir, necesariamente, de la relación de interdependencia sistémica entre experiencia y mediatización. Para enfocar las especificidades de dicha vinculación, postulamos la preeminencia de un carácter performativo en la puesta en contacto de cuerpos, territorios y dispositivos, facultada por los lenguajes icónico-indiciales. De tal modo, nuestra hipótesis es que una ecología performática de los restos y la deriva es lo que tiñe, en la actualidad, el sensorium de la mediatización.

Entendemos "lo performativo" a la manera de Fischer-Lichte (2011), como un concepto que proviene del mundo del arte y de la teoría de los actos de habla de Austin, que entiende a la cultura en su totalidad como performance. La noción de 'realización escénica' de los "estudios teatrales" de principios del siglo XX en Alemania es central en el desarrollo de esta perspectiva, que postula a la "obra" como "acontecimiento" y sitúa su interés no tanto en su producción como en su recepción. Este tipo de abordaje constituyó, en la década de 1960, un "giro performativo", a partir de la consideración de la realización escénica como un proceso de retroacción, 
de carácter autorreferencial y autopoiético, que se sustrae al control de las estrategias de montaje, y cuyo desarrollo es de naturaleza abierta e impredecible. El teatro, entonces, no como obra, sino como realización, como acción y ejecución en vivo (Fischer-Lichte, 2011), es lo que se traslada, desde un punto de vista analógico, al estudio de las performances comunicativas de la actualidad.

\section{Diagnósticos}

La experiencia moderna estuvo siempre vinculada a un modo peculiar de disponer la movilidad y el roce de los cuerpos en un espacio y tempo inéditos hasta entonces. La noción de 'flânerie', desarrollada por los autores clásicos de la modernidad, suponía, justamente, la emergencia de una novedad experiencial, cuyas consecuencias se advierten, por ejemplo, en el señalamiento benjaminiano de la emergencia de un nuevo sensorium o en la caracterización de Simmel del urbanita y el "nerviosismo" de la vida moderna; neurastenia, en realidad, dirá Simmel (Frisby, 1992). Para comprender genealógicamente dicho dispositivo, es necesario aclarar que las condiciones de producción de la flânerie correspondieron a una vivencia aún romántica - aunque no optimista - del capitalismo, en la cual el contacto entre cuerpos y mercancías en los distintos recovecos del espacio urbano (calles, pasajes, avenidas) podía figurarse como promesa de consumación del deseo y, por tanto, de enriquecimiento de la experiencia, aun en un contexto percibido ya, de manera ambivalente, como de pérdida o pobreza de la experiencia. Si bien, entonces, la "experiencia" moderna siempre tuvo que ver con una vivencia de pérdida, es decir, parafraseando a Benjamin (1982), con esa presencia irrepetible de una lejanía por más cercana que pueda estar, lo cierto es, sin embargo, que en los albores de la experiencia moderna dicha pérdida se jugaba, simultáneamente, en el azar de la potencialidad sensorial de los shocks de la erótica del contacto.

Dicha ambivalencia es lo que produce un efecto entre encantador y amenazante de la puesta en escena del cuerpo en la gran urbe, cuyo efecto exhibitivo hace que el gesto aventurero, extranjero o exótico se juegue como promesa de redención en un ambiente indefectiblemente ya en vías de enajenación. 
Ahora bien, es justamente el cambio de estatuto de dicha tensión entre experiencia y pobreza lo que en el sensorium actual ha mutado. La flânerie no resulta ya del todo operativa a la hora de abordar las maneras de estar en la actualidad, dado que la radical alteración de dicha pobreza de la experiencia hace que, en las condiciones presentes, la flânerie se advierta como una práctica más ingenua que nostálgica.

Cuando la ciudad —en cuanto metáfora del mundo en su conjuntoya casi no se percibe como un espacio imaginado de inquietante encuentro con la alteridad y, por lo mismo, como una ocasión de conmoción que se dirime en una apuesta por la fortuna del alma en un horizonte de riesgo subjetivo, sino como un territorio demasiado real en el cual se despliega la violenta materialidad de la segregación, cuyos crueles indicadores son, entre otros, tanto el despliegue de los individuos-en-estado-de-calle o en condiciones de vida indigente en el espacio urbano como las masas de migrantes y refugiados en estado de deriva en las fronteras globales, y todo ello en estado de exhibición simultánea con la vulgar ostentación de fulgurantes objetos y cuerpos del capitalismo supranacional; cuando esto sucede con tal violencia simbólica, no parece haber ya lugar, entonces, para el hecho social de la cándida flânerie. Imposibilitados de acceder a esa entusiasta erótica de los roces que dicha praxis promete, nos encontramos, al contrario, en estado-de-contacto y a la deriva en un contexto vivencial tendencialmente indeterminado. Parece imponerse, por tanto, un ahondamiento radical de la pobreza de la experiencia.

\section{Mediatización y mutación psíquica}

Desde el punto de vista del sujeto, esta profunda modificación de la experiencia social se produce en consonancia con una inédita mutación psíquica. El diagnóstico psicoanalítico prescribe, para nuestra época, también una economía psíquica en estado de deriva. Una época de crisis de puntos de referencia, de "dificultades para disponer de balizas" - $\mathrm{o}$, para decirlo de un modo técnico, de desprogramación-, en la cual "el goce prevalece sobre el deseo" (Melman, 2005, p. 10).

El peso que ocupa "lo mediático" en dicho diagnóstico es central: "Inflación de la imagen; recurso al derecho y a la justicia como comodines; 
reivindicaciones de víctimas de todo tipo; alienación en lo virtual; exigencia de riesgo cero" (Melman, 2005, p. 10). Tales son las condiciones de esta nueva economía psíquica, que resultaría de "la congruencia entre una economía liberal desenfrenada y una subjetividad que se cree liberada de toda deuda” (p. 13). A pesar de la profusa circulación —en nuestras regiones y también en el ámbito global - de discursos de tono populista, lo cierto es que el "triunfo" del llamado neoliberalismo se constata en el hecho de una profunda modificación psicosocial, ya que la globalización económica

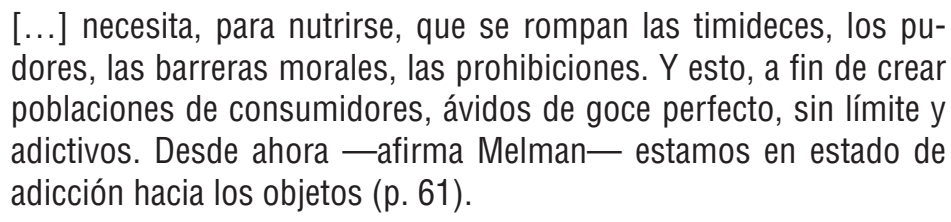

Dicha pulsión al goce no es nueva — constituyó, al contrario, uno de los argumentos centrales de, por ejemplo, la crítica frankfurtiana-, pero su dimensión ha cambiado, ya que en épocas previas se manifestaba bajo la forma de "actitudes de oposición" con respecto a normas que parecían infranqueables. Se podría sintetizar dicha mutación tomando aquello que presentaba con espíritu contestatario el situacionismo: Gocen sin trabas!!, consigna que se habría constituido, hoy en día, en un modo efectivo de ser, ya que nos autorizamos nosotros mismos nuestra propia existencia, constituimos nuestra propia área, nos autodiseñamos por propio impulso y a la deriva (Melman, 2005, p. 16). En 1967, en el clásico La sociedad del espectáculo, Guy Debord ya señalaba el "espectáculo" como un nuevo lazo social de carácter planetario. Entonces, desde este punto de vista, habríamos pasado de "una economía organizada por la represión a una economía organizada por la exhibición del goce"; es decir, "de la representación del objeto a su mera presentación” (Melman, 2005, p. 16). Los individuos, por tanto, tenemos que determinarnos a nosotros mismos tanto de manera singular como colectiva, sin ningún tipo de autoridad ni referencia, encontrándonos, simplemente, en estado de "gestión" (p. 17).

La validez de la propia subjetividad depende de una continua gestión de legitimación de carácter performante para ser reconocida (p.43). El self, de tal modo, "necesita ser confirmado sin cesar", produciendo una 
"fatiga" del sí mismo (p. 44), que coloca al sujeto entre la ansiedad y la depresión. Dicho mecanismo no es privativo solo de aquellos quienes, de algún modo, cuentan con las condiciones para el acceso legitimado al espacio público, sino también de los desplazados del sistema, cuyas apariciones a la luz de lo público implican una costosa puesta en escena y exhibición de los cuerpos en las calles de las ciudades, en los túneles fronterizos, en los mares colaterales. A las cándidas performances de las mascaradas del self que inundan la web con mil pasos de comedia banal, se suma la tragedia de los espectrales cuerpos en estado de deriva en los intersticios de las fronteras globales.

La "exigencia de transparencia", el "gusto por la luz", franquea, incluso, los lugares considerados tradicionalmente sagrados, hecho que se corrobora, por ejemplo, ante el "goce escópico de la muerte" (Melman, 2005, p. 20). Además del gusto por la necrofilia presente en muchas manifestaciones del arte contemporáneo, dicho goce se advierte, por ejemplo, en la profusa circulación global de las imágenes de las decapitaciones de Estado Islámico. La figura del "terrorista" viene así a constituirse en el significante más crudo de lo real, que aparece ya no mediado por lo simbólico, y produce una fascinación mediatizada, ya que se presenta como aquello que justamente está faltando, es decir, como "la figura del Amo absoluto", instancia "que decide sobre la vida y la muerte" (Melman, 2005, p. 177). Dichas pulsiones se despliegan mediante la búsqueda de "lo auténtico", que, para decirlo con otras palabras, no implican "ya un acercamiento organizado por la representación", sino por la búsqueda del "objeto mismo" (p. 21). Esta economía psicosocial hace sinergia con la posibilidad de captura automática de las actuales máquinas de comunicar, no ya dispuestas sobre el plano de la representación, sino sobre la presentación directa del objeto, la cual intenta sustraerse a cualquier mediación. Las lógicas del contacto de los dispositivos icónico-indiciales son, así, la condición material de este gusto por la exhibición, de este "gusto por la proximidad", incluso por la exhibición "(d)el interior del interior" (p. 24); especie de desnudo colectivo para una mirada total ante la cual nada puede ser disimulado, imponiéndose, de tal modo, y simultáneamente, como dispositivo de autovigilancia. Por su parte, la exhibición tanto de los cuerpos de migrantes y refugiados globales como de los 
desclasados de las ciudades perforan lo real también bajo la lógica del terror. Paradójicamente, el lugar de lo abyecto — que siempre la cultura intentó ocultar-adquiere, en la mediatización actual, una macabra visibilidad.

Desde el punto de vista del individuo en sociedades mediatizadas, se advierte que sus identificaciones comunitarias - a falta de un ideal asumido - no podrían no ser momentáneas. En la tendencia actual a la igualitarización de los goces —en este populismo de distribución equitativa de los goces-, el zapeo no solo se considera una práctica que logró generalización, sino que se constituye en matriz subjetiva. El sujeto, de tal modo, se encontraría a la deriva entre goces diversos, desde ahora accesibles a todos (Melman, 2005, p. 122). Al no contar ya con un "ideal asumido", la pertenencia del sujeto a una comunidad será solo momentánea, cambiando de acuerdo con el lugar desde donde se habla, es decir, "según la información" (p.103). Para un sujeto que no es más que "máscara de una subjetividad móvil", el lugar del otro es ocupado por el lugar mutante de "las informaciones": "Ya no el economista, el estratega, el sabio, o el cura ... quien ocupa el primer lugar es el hombre de comunicación" (p. 104). De tal modo, nos encontramos con una "polisubjetividad", que, envuelta en las redes, se cree capaz de "tener vidas múltiples" y "goces diversos" (pp. 103-104).

Si consideramos dicho diagnóstico desde el punto de vista del lazo social, las comunidades reunidas alrededor de un mismo goce suponen una complicación, ya que toda asociación pasional se encuentra basada solo en el apoyo tomado en otros, y en la medida en que los otros comparten el mismo goce, y en espejo. Se trataría, nuevamente, de sujetos a la deriva, llevados por un mismo goce - como en el lecho de un río-, que parecen haberse liberado de sus propias leyes — contando, solo, las leyes del río: "Rebaños momentáneos de gente que siente el mismo placer, al mismo tiempo, en el mismo lugar y se contemplan en la imagen del otro" (p. 40).

Estas asociaciones "reunidas alrededor de un mismo goce" suponen, entonces, un lazo social empobrecido, dado que un vínculo atado solo por una misma pasión no constituye un lazo social propiamente dicho (p. 139). 
Este parece ser el diagnóstico para una cultura en que la fabricación de objetos, de máquinas y de dispositivos aptos para satisfacer los orificios corporales se ha convertido en una exigencia. Se trata de artificios maravillosos capaces de saturar hasta el agotamiento los orificios visuales y auditivos; $y$, de tal modo, los cuerpos vibran, ávidos de goce perfecto, sin límite y adictivos ( $\mathrm{p}$. 34). Son los "goces orificiales" de una nueva economía psíquica, goces que para Freud eran pregenitales, y que hoy parecen estar primando, incluso, sobre el goce sexual (p. 35).

Como decíamos, en dichas asociaciones pasionales, la validez del propio yo solo se verifica en su capacidad performante, colocando al sujeto en la fatiga de ser él mismo. La preeminencia performática de lo icónico-indicial hace que las palabras pierdan eficacia y se debiliten, con ello, las posibilidades de regulación del contacto. El espacio urbano y los territorios fronterizos aparecen, en tal contexto, como dispositivos de despliegue de la segregación, de la violencia, de lo delincuencial, o, dicho de un modo más concreto, como un campo de batalla. Pero, como todo campo operativo, este nunca es completo, y es, justamente, sobre los restos de dicha incompletud que trabaja la cultura.

Para decirlo de otro modo, son, justamente, los restos, los fragmentos, los detalles - los fenómenos residuales - , los que se posicionan como causa de la posibilidad de desvíos resistenciales o paródicos que resignifican la cultura. Así como el sujeto, desde el punto de vista de su aparato psíquico, recomienza siempre a partir de sus propios restos, del mismo modo la cultura encuentra, en sus fenómenos residuales, y mediante la estructural productividad de lo excremencial, su posibilidad de reinscripción.

\section{Migrantes, refugiados y desclasados en la mediatización actual}

Desde un punto de vista global, los sucesos relativos a las grandes masas de migrantes y refugiados que buscan llegar a Europa ponen de manifiesto el lugar central que ocupa la mediatización. Solo cinco años transcurrieron entre la circulación global de las imágenes de la inmolación con fuego de Mohamed Bouazizi en Túnez, el 17 de diciembre de 2010, en la llamada 
Primavera Árabe (Valdettaro, 2012), yla fotografía del niño sirio Aylan Kurdi, de 3 años, arrojado muerto por el mar en una playa turca, la cual se mediatizó a partir del 2 de septiembre de 2015. La imagen del niño ahogado hace índice con la del joven autoincendiado un lustro atrás: mar y fuego como símbolos potentes de masas (Canetti, 1994 [1960], p. 15), intérpretes inequívocos del destino actual de las masas segregadas que se encuentran a la deriva tanto en la naturaleza como en la cultura. El componente sacrificial de dichas imágenes despliega una narrativa en la cual se instala un espacio ambivalente; por una parte, para las propias masas migrantes, el componente de ofrenda de las imágenes del niño muerto se torna heroico y emblema identificatorio, confiriéndose, simultáneamente, una dimensión de sentido performático-publicitario en cuanto ícono global de las demandas de los contingentes de individuos segregados; por otra parte, para las ciudadanías occidentales bienpensantes, las cruentas imágenes de dicho componente segregado de las masas migrantes ocurre bajo la lógica de un don impensado (Mauss, 1971), que instala una cadena de deudas con la propia especie, manifestada, en ocasiones, como responsabilidad, y en otras, directamente, como culpa. Aunque también, a dicha afección de un estado de falta hacia la humanidad de la cual formamos parte, se suman otras actitudes de carácter contrario, las cuales refuerzan la lógica segregatoria xenófoba. Sin poder medir magnitudes de una y otra actitud, lo cierto es que ambas se mediatizan de manera ubicua por las redes globales, instalando la condición humana en un estado de perplejidad, cuya imprevisibilidad amenaza de una manera radical el lazo social en todos sus niveles.

La turística playa en la cual el mar escupió los cuerpos de varios niños, entre ellos el de Aylan Kurdi y el de su hermano Galip, de 5 años, devela la profunda impotencia de los organismos globales y pone al turismo internacional en una contigüidad con el horror que parece, por momentos, no tener efectos. Sin embargo, la prensa global declara, con su habitual estridencia, que el niño muerto "despertó la ira de Occidente ante la tragedia del flujo migratorio" (ABC.es, 2015).

El poder icónico-indicial de esa fotografía de un niño análogo a cualquier otro occidental yaciendo en la arena, casi como durmiendo, produjo 
un instantáneo bucle de retroalimentación en la mediatización global, y la historia se desplegó plena de detalles: estaban navegando junto con otras 18 personas hacia Kos, una isla griega, en dos embarcaciones que habían partido de Akyarlar en la península de Bodrum (Siria) (ABC.es, 2015). El "drama migratorio" produjo, a septiembre de 2015, según la prensa, "cerca de 3.000 muertes" en las costas ( $A B C$.es, 2015), siendo que en abril se consignaban 1600 migrantes muertos en el Mediterráneo, considerada "la ruta migratoria más mortífera del mundo”, según la Alto Comisionado de las Naciones Unidas para los Refugiados (Acnur) (BBC Mundo, 2015). Estos números demuestran la escalada inaudita del fenómeno, cuya lógica se parece a la de la "cismogénesis" planteada por Bateson (1997, p. 118). Según datos de la Agencia de Fronteras de la Unión Europea (Frontex), son mayoría los que huyen de la guerra civil en Siria, y los eritreos que escapan de la represión (BBC Mundo, 2015). La ciudad de Zintan, en Libia —a unos $100 \mathrm{~km}$ del Mediterráneo- es uno de los puntos de partida para los migrantes, situación facilitada por la inexistencia de un gobierno efectivo desde la caída de Muamar el Gadafi en 2011 (BBC Mundo, 2015). Asimismo, la ruta del Sahara es tan letal como la del Mediterráneo, siendo la ciudad de Gao, en el noreste de Mali, la entrada a la "promesa" de Europa, que implica una travesía en camión por el desierto durante seis días durante la cual muchos mueren. Para llegar a Argelia, las redes de traficantes de inmigrantes cobran a cientos de africanos unos US $\$ 400$ cada uno, mientras que en la ruta del Mediterráneo se pagan, aproximadamente, US $\$ 2500$ por persona ( $B B C$ Mundo, 2015). El 19 de abril de 2015 murieron cerca de 800 personas por el naufragio del barco en que viajaban, que había salido de Libia, del cual sobrevivieron solo 28 personas. Fue, hasta ese momento, el "naufragio más mortífero en el Mediterráneo” (BBC Mundo, 2015). Mare Nostrum — misión de búsqueda y rescate de migrantes de la armada italiana- rescató 170000 personas hasta octubre de 2014 en que estuvo en funcionamiento, y fue reemplazada por Tritón —misión de la Unión Europea- que rescató 11000 migrantes en los últimos dos meses de 2014 (BBC Mundo, 2015). La llamada "crisis humanitaria" de los migrantes tuvo cierta repercusión el 20 de junio de este año, durante el Día Mundial del Refugiado, cuando distintas asociaciones, partidos políticos y sindicatos reclamaron cambios a la Unión Europea. Según Acnur, casi 60 millones de personas se 
encuentran en la actualidad en estado forzoso de desplazamiento, la cifra más alta desde el fin de la Segunda Guerra Mundial (La Vanguardia, 2015). En Madrid se manifestaron Amnistía Internacional, Cáritas Española, Cáritas Europa, el PSOE, el sindicato Comisiones Obreras, etcétera, reclamando a la Unión Europea una solución humanitaria para esta crisis. Mientras que Vodafone España y el Comité Español de Acnur pusieron en marcha una campaña de educación en los campos de refugiados mediante Instant Classroom, una "escuela digital en una caja”, que contiene un portátil y 25 tabletas con programas educativos, preparada para operar en zonas con escasa electricidad y conexión a internet (La Vanguardia, 2015).

A pesar de la contundencia de todos estos datos y de que la crisis migratoria comenzó hace aproximadamente cuatro años, hasta que no se difundió la imagen del niño sirio muerto no se produjeron efectos concretos en las políticas europeas de migración. La circulación global de esa fotografía puede considerarse como una metáfora tanto de las modalidades operatorias de la mediatización actual como de la gramática espectacular y exhibitiva de la percepción mediatizada del mundo en nuestra contemporaneidad. Estamos, para decirlo claramente, en una nueva ecología de la mediatización, en la cual los cuerpos se encuentran sobreexhibidos en su despiadada deriva.

Así como las imágenes de decenas de inmolaciones —además de la de Bouazizi ya referida - durante la Primavera Árabe, las de los niños muertos ahogados en el contexto de la actual crisis migratoria se tornan en eslóganes sacrificiales productivos, ya que en su mismo desarrollo adquieren un componente político, aunque de profunda indeterminación. Su circulación por las redes globales se dirime en la compleja semantización del "contagio" universal: "contagio" en cuanto operatoria nuclear de los símbolos de masas que logran un nivel de "contacto" sin precedentes entre los expulsados del sistema; y "contagio" virósico de las redes mediante la exhibición tóxica de imágenes cruentas para un perverso y fascinado omnivoyeur global. Como decíamos en otro lugar (Valdettaro, 2012), constituye dicho mecanismo una costosa operatoria de visibilización de la abyección 
humana, que en un instante se descarga en la mediatización icónico-indicial universal, instaurando un vínculo somático: la inmediación de las interfaces actuales se constituye, de tal modo, en condición de producción de dicha apelación afectivo-concreta, y demuestra el carácter ambiental de las tecnologías de captura automática de "lo real", y digo "lo real" y no la mera realidad, ya que lo que insiste ahí en inscribirse es aquello que, sin embargo, nunca puede lograrlo del todo (Melman, 2005), dado que la simbolización de la degradación humana presenta los rasgos del síntoma de la cultura actual, y son apenas ciertos trazos los que quedan inscriptos en el automatismo viral de las tecnologías, suficientes, sin embargo, para indicar la radicalidad del malestar civilizatorio.

Pero es, justamente, a partir de la circulación de dichos rasgos y fragmentos que la mediatización actual demuestra su poder, ya que solo a partir de la viralización de la fotografía del niño sirio muerto, en cuanto significante articulador de un drama migratorio que lleva largo tiempo, se produjeron efectos concretos. El sentimiento de responsabilidad o culpa de una civilización entrampada en su propio discurso de fraternidad, libertad e igualdad se expresó de manera casi inocente: en Múnich (Alemania), recibieron a los niños migrantes con peluches (lanacion.com, 2015c), rescatando, de tal modo, una noción de protección a la infancia, que en dicho contexto demuestra el cinismo declamativo de los discursos de derechos humanos. En viaje desde Hungría, y luego del agobio de una travesía en tren plagada de obstáculos, los regalos alemanes a los niños segregados parecen articularse como contra-don de aquello que la presencia de sus cuerpos escupe, a la manera de una lacra, en el vertedero de la realidad global. Las sonrisas de los migrantes, como devolución de dicho gesto amistoso en la moderna estación de Múnich, pueden ser vistas como simulacro paradojal de las relaciones internacionales institucionalizadas por las cuales Alemania y Austria sellaron un acuerdo en Budapest, presentado como "emocionante actitud solidaria" (lanacion.com, 2015c). Ropas, juguetes, peluches, lápices de colores, libros infantiles, etcétera, constituyen una lista de indecible candidez, cuya misión expiatoria no parece resolver el drama de la segregación. El primer tren que arribó a las $13.20 \mathrm{~h}$ de Alemania el 5 de septiembre de 2015 a la estación de Múnich cargaba 450 refugiados, estimándose que arribarían 
hasta 10000 migrantes en dicha jornada (lanacion.com, 2015c). Simultáneamente, luego de dos días de reuniones, los ministros del bloque europeo acordaban reforzar la cooperación, comprometiéndose a proteger a los refugiados y tratar la crisis de Siria. Los puntos del acuerdo son los siguientes: "Asegurar protección de las personas que lo necesiten, gestionar su situación en total respeto de los derechos humanos, luchar contra los traficantes de seres humanos, reforzar la asociación con los países de origen y tránsito, y abordar los acuerdos de readmisión y devolución, y tratar las causas raíces de la llegada de refugiados" (lanacion.com, 2015a). El compromiso de la Comisión Europea también incluye la creación de "un fondo fiduciario de apoyo a países africanos", abordar no solo la situación de Siria, sino también de Libia, y el diseño de una estrategia concreta para "el reparto" de aproximadamente 120000 refugiados entre los Estados miembros (lanacion.com, 2015a). La "estabilización de las fronteras" —es decir, el control antes del "reparto" en "cuotas" de los refugiados - fue una petición de Eslovaquia y Lituania. Con contundencia, el ministro eslovaco de Exteriores, Miroslav Lajcak, declaró: "¿Cómo se puede discutir de cuotas cuando sigue habiendo una gran entrada de refugiados y no sabemos de qué cifra estamos hablando?" (lanacion.com, 2015a). El discurso del ministro eslovaco mostró, de modo contundente, la realidad de la situación. Según él, sucedería un "efecto llamada" entre los refugiados "si supieran que van a ser distribuidos por los Estados miembros" (lanacion.com, 2015a). La verdad se asoma en estos dichos; ellos revelan la lógica profunda de la situación: los migrantes y refugiados se encuentran, efectivamente, conectados $y$ en estado-de-llamada; y no alcanzan los peluches y regalos para desactivar dicho efecto escalante y disruptor de la interconexión de esos cuerpos en deriva.

No se puede ser incautos cuando los cuerpos se encuentran desprotegidos y en estado de deriva, y dicho saber de los segregados autoconectados por los dispositivos móviles en las distintas rutas migratorias les asegura un poder de choque y rebelión que se materializa en demandas concretas: contra la Unión Europea, una larga marcha desde Budapest hacia la frontera con Austria logró que los gobiernos de Viena y Berlín autorizaran el cruce (lanacion.com, 2015b), provocando, también — como reseñamos antes- 
una reacción concreta por parte de aquella. Y todo ello por el impacto global de la fotografía de un solo niño muerto, entre los miles previamente sacrificados. Lo inhumano se condensó, así, en la imagen del cuerpo yaciente de Aylan Kurdi, y produjo un contagio inevitable. Simultáneamente a la marcha de Budapest, otros 300 migrantes escaparon de un centro de refugiados que Hungría había montado en la frontera con Serbia, en la ciudad de Roszke; y otros 500 se negaron a abandonar la estación de trenes de Bicske, rechazando su traslado a un centro de recepción (lanacion.com, 2015b). La prensa apunta claramente dicha situación: "Los tres casos —Budapest, Roszke y Bicske — configuraron una rebelión simultánea, masiva y desesperada de los recién llegados de Medio Oriente, África y Asia, ante el temor de que la Unión Europea les cierre sus puertas y los mande de vuelta al caos de la guerra, la violencia y la miseria de sus países de origen" (lanacion.com, 2015b). Lo inédito de la situación tiene que ver, justamente, con la ecología de la mediatización: la posibilidad de la acción simultánea y masiva se encuentra habilitada, parafraseando a Verón (2013), por la conmutación universal del contacto provista por los dispositivos. Ante ello, también resultan elocuentes las palabras del primer ministro húngaro, Viktor Orban: "Si no protegemos nuestras fronteras vendrán a Europa diez millones de migrantes”, declaró a la prensa (lanacion.com, 2015b). En tal contexto, la figura de la canciller alemana Angela Merkel inesperadamente quedó atrapada en la fuerza significante de su propio nombre cobrando un matiz angelical: la columna que avanzaba por la ruta en peregrinación desde Budapest mostraba, de manera identificatoria, imágenes de la canciller (lanacion.com, 2015b), figuración investida, repentinamente, de un sentido esperanzador y de generosidad, y Alemania, en contigüidad, semantizada como meca y meta por alcanzar. En síntesis, el "reparto" en cuotas de 120000 refugiados se encuentra en marcha, aunque ni República Checa, ni Eslovaquia, ni Hungría, ni Polonia aceptarán dicha "imposición” (lanacion.com, 2015b).

Sufrimiento, solidaridad y expulsión como ambivalentes vectores pasionales de una mediatización de la ignominia que produce efectos paradojales. En Múnich gente común y voluntarios acogen a los migrantes $\mathrm{y}$ refugiados que arriban agotados, brindándoles comida, ropa, juguetes y 
asistencia médica (Corradini, 2015b), en una especie de actitud caritativa que en realidad los prepara para el "registro" y posterior envío a los campos de refugiados: "Los refugiados que llegan a Munich son repartidos en el país en función de un mapa establecido por un programa informático bautizado EASY, que los despacha en tiempo real" (Corradini, 2015b); paradojas, decíamos, de la mediatización. Mientras tanto, campañas de solidaridad lanzadas por personalidades prominentes de Alemania se manifiestan en favor de los migrantes, incluida una del diario Bild, "históricamente célebre por sus posiciones antiinmigración” (Corradini, 2015b), y la organización Refugees Welcome se ocupa de contactar a los migrantes y refugiados con personas dispuestas a alojarlos en sus viviendas: "Más de 780 alemanes se inscribieron en pocos días" (Corradini, 2015b). Por su parte, Angela Merkel declaró: "Estoy orgullosa de ver la cantidad de ciudadanos que se comprometen a favor de los refugiados", condenando, simultáneamente, las actitudes racistas (Corradini, 2015b). El acuerdo franco-alemán "sobre la obligatoriedad del cupo de acogida de cada país de la Unión Europea, como sobre la adopción de reglas comunes para el otorgamiento de asilo" (Venturini, 2015), vehiculizado por Merkel, no evita la realidad política de la segregación: el Frente Nacional, en Francia, debe su éxito político a sus posturas contra la inmigración; los conservadores británicos se caracterizan por la misma actitud cuasixenófoba; los neonazis de Amanecer Dorado en Grecia; la Liga Norte y de las Cinco Estrellas en Italia; todos ellos manifiestan su hostilidad a los migrantes (Venturini, 2015).

La realidad de las migraciones se presenta con extrema crueldad, como el caso de los 71 migrantes sirios encontrados muertos, asfixiados, en un camión de los traficantes de los Balcanes abandonado cerca de Viena, o los 105 cadáveres aparecidos en las costas de Libia, ahogados tras un naufragio de una embarcación en mal estado de un traficante, hechos sucedidos el 28 de agosto de 2015 (Corradini, 2015a). Por esa ruta - Grecia, Macedonia, Serbia, Hungría -, llamada "el cementerio del Mediterráneo", circularon casi 44000 personas durante 2014, mientras que durante 2015 llegaron a Grecia 50000 solo en julio según Acnur. Se calcula, en lo que va de 2015, una circulación de unos 200000 migrantes (Corradini, 2015a). A Budapest, la "puerta de entrada a Europa", arribaron 140000 personas desde comienzos 
de año, el doble que en 2014. La respuesta: criminalización de los ingresos ilegales y construcción de una barrera de contención de $175 \mathrm{~km}$ (Corradini, 2015a). Los migrantes, en su mayoría, provienen de Siria e Irak, y en general eligen la ruta de los Balcanes, considerada menos peligrosa que la del Mediterráneo. El objetivo es alcanzar Alemania o el Reino Unido. Los que salen de África optan por el Mediterráneo: más de 300000 migrantes lo atravesaron durante lo que va de 2015, mientras que en 2014 fueron 219 000. Las Naciones Unidas reportan 2500 muertos en aguas del Mediterráneo (Corradini, 2015a).

\section{La productividad de los restos}

Sin embargo, en dicho contexto paradojal, los migrantes producen una productividad de sus propios restos - de lo que va quedando de ellos - a través de las redes sociales. Actuando en cadena y en tiempo real, el pulso de su circulación por las rutas y las redes promueve una inmediatez global del contacto que coloca a la alteridad radical como el fantasma que hoy recorre Europa. Esta época profundamente segregatoria, violenta, cínica y conflictual se encuentra atravesada por la indeterminación constitutiva de los cuerpos-actuantes-en-cadena vía los dispositivos móviles. Es posible que su dimensión épica produzca, tal vez, bifurcaciones impensadas, como las atinentes a la viralización de una sola fotografía de un niño muerto.

De tal modo, la “crisis del Mediterráneo" es escenario, también, de esta peculiar interfaz entre dispositivos y cuerpos en tránsito. Miles de migrantes, refugiados y expatriados de África y Medio Oriente necesitan sus celulares y dispositivos tanto como el agua y el refugio (Brunwasser, 2015). Un profesor proveniente de Siria, sentado en una plaza de Belgrado, dice: "Cada vez que paso por un nuevo país, me compro una tarjeta SIM para activar Internet y descargarme el mapa para saber dónde estoy" (Brunwasser, 2015). Mediante los teléfonos inteligentes, se van planificando los movimientos hacia Europa: "Sin mi celular, no habría llegado jamás a destino", agrega otro migrante (Brunwasser, 2015). Apunta el cronista que "esta crisis de refugiados lleva la marca transformadora de la innovación tecnológica, que ha facilitado los movimientos de millones de personas" (Brunwasser, 2015), y a partir de su uso se van señalando las rutas más exitosas, como las que 
circulan unas 3000 personas por día atravesando los Balcanes para cruzar la frontera de Grecia a Macedonia: dispositivos, mapas satelitales, GPS, redes sociales, WhatsApp, hacen a un tipo de movilidad peculiar de contingentes que, en estado de desesperada deriva, logran construir itinerarios en tiempo real detectando los mejores caminos y hospedajes, comunicándose con sus familias y tratando de evitar toda clase de peligros, desde los arrestos en las fronteras hasta los traficantes de personas, quienes cuentan, también, con páginas de Facebook en las cuales ofrecen sus "servicios", a la manera de las agencias de turismo (Brunwasser, 2015). ${ }^{2}$

Pero los migrantes cuentan, también, con sus propias herramientas: "Smuggling into the EU" o "How to Emigrate to Europe" son foros de discusión públicos y privados, en los cuales se comparten fotografías y videos del trayecto tomados con sus celulares (Brunwasser, 2015). La autonomía que permiten los dispositivos produjo una baja en la tarifa de los traficantes, quedando solo en su dominio el cruce entre Turquía y Grecia (Brunwasser, 2015). De tal modo, los segregados del sistema logran, a partir de los dispositivos, señalizar de una manera certera su deriva por los desiertos, por los mares y las fronteras, y una creciente visibilidad. Síntoma paradojal de una cultura mediatizada que no logra invisibilizar aquello que se segrega. Son casi 60 millones las personas que vagan por el mundo en la actualidad; casi 20 millones de las cuales se consideran "refugiados", que huyen de guerras o persecuciones religiosas o políticas (Edwards, 2015).

Del mismo modo que los migrantes, se encuentran en estado de excepción y a la deriva los millones de habitantes de las villas miseria de las ciudades. Aquellos que no entran en el "reparto de lo sensible", los que "nocuentan" (Rancière, 2009), los indocumentados de todo tipo, los excluidos del sistema, con la conectividad, logran su visibilización. En la actualidad, hay, por ejemplo, en Buenos Aires, "14 villas, 24 asentamientos y dos núcleos habitacionales transitorios, según la Dirección General de Estadística

2 "En el grupo de Facebook en idioma árabe Trafficking to Europe, un traficante ofrece un $50 \%$ de descuento para menores de cinco años. La tarifa de 1700 euros que cuesta el viaje desde Estambul hasta Salónica, Grecia, incluye el trayecto en auto a la frontera y una caminata de dos horas para cruzarla. "Salidas diarias", se jactan los traficantes en la página. El grupo Trafficking to Europe tiene 6057 miembros y es apenas un pequeño rincón de todo ese mundo de redes sociales a las que pueden recurrir los sirios y otros migrantes" (Brunwasser, 2015). 
y Censos local”, con una población estimada en más de 300000 personas, "70 \% más que hace cuatro años" (Tomino, 2015). Es en la villa 1-11-14, en el Bajo Flores, donde más se utiliza wifi gratuito (Tomino, 2015). Contando Buenos Aires con 377 puntos de red, ${ }^{3}$ en ese barrio precario "se consumen 21,7 gigabytes (GB) por día, el 3,5\% del total de la red (620 GB diarios)" (Tomino, 2015). Junto con las villas 21-24, 20 y 6, Los Piletones, Ciudad Oculta y el Barrio Ramón Carrillo, y a pesar de las recurrentes saturaciones de la red, se encuentra al tope del consumo de conectividad gratuita en Buenos Aires, llegando, en conjunto, a $15 \%$ de la demanda diaria (93 GB) (Tomino, 2015) y superando los espacios públicos con acceso libre a internet, como los museos, las estaciones de subte, las plazas, los centros comunales (Tomino, 2015), en los cuales el temor a los robos de los dispositivos atenta contra el consumo.

\section{Exploraciones de una ecología de la mediatización de los restos y la deriva}

¿Desde qué lugares es posible posicionar la investigación de esta ecología performática mediatizada del sujeto individual y social? Si lo que aparece en la trama de lo social son las huellas de los restos de unos itinerarios inciertos de los sujetos tanto desde el punto de vista psíquico como social, cultural y político, ¿es posible, con tales condiciones, arribar a hipótesis explicativas generalistas? Al contrario, opino que cualquier intento de ejercicio intelectual totalizador se queda corto ante la radical contingencia del presente. Se hace necesario, por tanto, ubicar la investigación desde un punto de vista exploratorio y conjetural, que mediante formas rapsódicas pueda instalar una narración del registro de dichos restos para mapear, como un radar, la gramática de los movimientos. Las modalidades de los modos de vivir en la actualidad imponen una mirada abductiva que pueda explorar las condiciones de la experiencia haciendo foco en la "documentalidad" (Chejfec, citado en Gigena, 2015) en cuanto matriz de registro y archivo de los restos de la deriva del sensorium de nuestra época. La investigación, entonces, también, como intervención performática, de carácter experiencial, ligada a la realidad de los lenguajes icónico-indiciales y de las lógicas del contacto entre los cuerpos, los territorios y los dispositivos, imbricada

3 "La red BA Wi-Fi está disponible las 24 horas, los 365 días del año. Ofrece 377 puntos de acceso que permiten que se conecten hasta 30 personas en simultáneo. En junio pasado, la Ciudad contabilizó más de 200.000 usuarios mensuales del servicio" (Tomino, 2015). 
con esa mutación de la experiencia que reseñábamos, y que puede constituir, del mismo modo, una deriva intelectual.

Los ensayos y las crónicas son los géneros que más se adaptan a esa atención flotante, que requiere la exploración de las condiciones de nuestra contemporaneidad. Modalidades de registro de una creciente complejidad, como nueva base experimental investigativa, capaz de detectar la emergencia de lo anómalo, de los fenómenos residuales, que insisten en inscribirse en una mediatización que se quiere transparente y democrática. Ahora bien, nos preguntamos: ¿ cómo investigar — es decir, explorar- dichas derivas y fenómenos residuales, sin caer en la denuncia, el costumbrismo o la fascinación identificatoria? Es en función de una respuesta a dicha pregunta que hablábamos de "documentalidad". Como plantea Bernabé: "El factor documental no refiere a una forma de documentar o referir a lo real, sino que señala una puesta en funcionamiento del dispositivo tecnológico para ver y oír... registra las huellas de lo real en el campo perceptivo" (2015, p. 9). Para nuestros propósitos, se trata, entonces de una puesta en funcionamiento del aparato investigativo capaz de registrar aquellos fragmentos por los cuales apenas asoma la lógica profunda de la mediatización.

Las escrituras contemporáneas indican un camino para ello: se trata de un "campo experimental", en el cual se despliega un vínculo "entre lo real y el arte de narrar" alejado de la lógica del "reflejo" de la literatura llamada realista, y, procediendo, al contrario, con una actitud archivista-descriptiva (Bernabé, 2015, p. 2). Semejante al automatismo de la captura de las máquinas actuales de comunicar, cuya gramática no descansa ya en la previsibilidad del lecho epistemológico de la representación, sino que opera por mera presentación, la investigación —en su carácter de literaturase encuentra, entonces, en dicho desafío de una documentalidad de "notas tomadas en vivo", de "textos imprecisos e indeterminados", de encuentro con "lo discontinuo" (p. 11), y en estado de deriva, también, como el objeto de estudio, que — dada su complejidad — ha devenido casi enigma. Esas "series textuales" que desafían el realismo lo que intentan es "transferir algo de lo real en esforzada batalla contra la opacidad irreductible del lenguaje" (Bernabé, 2006, p. 8), pero lejos de la lógica del reflejo, el re- 
gistro de los fenómenos residuales, de los restos y los fragmentos adquiere más la lógica de las vanguardias: el montaje, el collage, la superposición de elementos de distintas series, cuya contigüidad resulta impensable pero significativa (p. 9). Se trata, en definitiva, no de un realismo, sino de una curiosidad, de un deseo de "aspiración realista" (p. 11). Como señala Chejfec, "en la literatura es constatable dicha búsqueda de documentalidad", entendiendo a la escritura como "experiencia" y a "la ficción como testimonio documental” (Chejfec, citado en Gigena, 2015, p. 11). Chejfec entiende justamente a "la documentalidad" como "un modo de desestabilizar el sentido común acerca de lo que es ficción y lo que es testimonio”. El documento se entiende, entonces, no como "documentalismo", dado que "los hechos documentables no son necesariamente reales, aunque poseen un estatuto documental [cursivas nuestras]" (Chejfec, citado en Gigena, 2015, p. 11). Se trata, como apunta Bernabé sobre la literatura de Chejfec, de una modalidad de "narrador-caminante", de "atención flotante", del estatuto de los "objetos como emblemas de un mundo en descomposición” (2015, p. 12).

Un particular modo descriptivo de registrar los restos, los fragmentos, los detalles, que encontramos, genealógicamente, en el vínculo entre cámara, movilidad, cuerpo y territorio; en los experimentos cinematográficos como los de Vertov; en ciertos componentes del programa de las vanguardias históricas, y, más acá, también, en el situacionismo y el land art. Un gesto documental que, sin embargo, no podría ser objetivo, ya que, como escribió Kracauer en 1928 en sus notas sobre el fenómeno de los empleados en Berlín: "Sumergirse en una ciudad es emprender una expedición más arriesgada que viajar por África para rodar una película” (citado en Bernabé, 2015, p. 5). De tal modo, vivir, investigar, explorar, una ciudad, un territorio, implica, por tanto, un riesgo mayor a hacer una película en un ambiente exótico.

Pero lo notable es que, desde entonces - es decir, desde ese momento de incrustación del sujeto con los dispositivos - no es posible evaluar un riesgo si no es a partir de lo que el dispositivo monta. De tal modo, desde los experimentos de Vertov, por ejemplo, a la actual captura automática digital y algorítmica, lo que se advierte es la compleja relación entre realidad y documento, ya que aquello que se registra no es, en sentido estricto, real, sino 
— si se me permite el término - cuasirreal. Los archivos de estos índices de efímera realidad compondrán el jeroglífico de lo actual. En tal programa se incluyen temas, como el de la movilidad en cuanto experiencia mediante la incorporación en la vida cotidiana de diversos dispositivos de comunicación e información portátiles — tabletas, teléfonos inteligentes, relojes portátiles inteligentes-, en los cuales confluyen sistemas de geolocalización, cámaras de video, reproductores de música hasta monitores de ritmo cardiaco, pasando por la dilucidación de los vínculos entre ciudad física y ciudad virtual y las figuras urbanas correspondientes, los casos de movilizaciones de masas y su relación con el uso de dispositivos móviles en la emergencia de sujetos políticos de nuevo tipo y colectivos sin identidad formal, hasta exploraciones del registro urbano a partir del big data y los propios datos generados por usuarios. La indicialidad de los dispositivos de la mediatización actual nos coloca frente al dato o la prueba como crónica de aquello que los sujetos experimentan en un sistema crecientemente entrópico.

En esta realidad de una mediatización de los restos y la deriva, el investigador, a la manera de un explorador, no puede proceder más que por ensayo y error. El ensayo, según Adorno (1962), intenta "penetrar lo que se esconde como objetividad detrás de la fachada” (p. 12). Se distancia de las teorías sistemáticas y es, al contrario, "fragmentario y accidental" (p. 21): "El ensayo piensa discontinuamente, como la realidad es discontinua, y encuentra su unidad a través de las rupturas, no intentado taparlas” (p. 27). Resulta elocuente la cita de Max Bense que presenta Adorno: "Así, pues, se diferencia un ensayo de un tratado. Escribe ensayísticamente el que compone experimentando, el que vuelve y revuelve, interroga, palpa, examina, atraviesa su objeto con la reflexión, el que parte hacia él desde diversas vertientes y reúne en su mirada espiritual todo lo que ve y da palabra a todo lo que el objeto permite ver bajo las condiciones aceptadas y puestas al escribir” (Bense, citado en Adorno, 1962, p. 28). La experiencia de la escritura ensayística se encuentra con "lo opaco de sus objetos" (p. 35), y su objeto es siempre "lo nuevo en tanto que nuevo, no traducible a lo viejo de las formas existentes", buscando "conexiones horizontales entre los elementos, conexiones para las cuales no tiene sitio la lógica discursiva” (p. 34). 
Ante la perplejidad que ocasionan las profundas mutaciones de la ecología de la mediatización actual, la forma-ensayo nos permite una investigación como vivencia conjetural que, ante la radicalidad de la novedad, se constituye en "la forma crítica por excelencia", en "crítica de la ideología", siendo la crítica, necesariamente, una experimentación (p. 30), único modo de afrontar, en la actualidad, la extrañeza de lo imprevisto de la deriva en la ecología de una mediatización de creciente indeterminación.

\section{Referencias}

Adorno, T. (1962). El ensayo como forma. En Notas de literatura (pp. 11-36). Barcelona: Ariel.

Bateson, G. (1982). Espíritu y naturaleza. Buenos Aires: Amorrortu.

BBC Mundo (2015, 22 de abril). Tragedia del Mediterráneo: así es la ruta de migración más mortífera del mundo. Recuperado de http:// www.bbc.com/mundo/noticias/2015/04/150421_migrantes_ ruta_europa_testimonios_ac

Benjamin, W. (1982). La obra de arte en la época de su reproductibilidad técnica. En Discursos Interrumpidos I. Madrid: Taurus.

Bernabé, M. (2006). Prólogo. En M. S. Cristoff (comp.), Idea crónica, Rosario, Argentina: Beatriz Viterbo.

Bernabé, M. (2015). Otra vuelta de crónica (en prensa). Rosario, Argentina: Universidad Nacional de Rosario.

Brunwasser, M. (2015, 27 de agosto). Los smartphones, tan indispensables como el agua para los sin papeles. En lanacion.com. Recuperado el 1 de enero de 2015 de http:/ / www.lanacion.com.ar/1822522-lossmartphones-tan-indispensables-como-el-agua-para-los-sin-papeles

Canetti, E. (1994 [1960]). Masa y poder. Barcelona: Muchnik. 
Corradini, L. (2015a, 29 de agosto). Europa no sale del espanto: otra tragedia deja más de 100 muertos. En lanacion.com. Recuperado el 30 de agosto de 2015 de http: / /www.lanacion.com.ar/1823199-europa-no-sale-del-espanto-otra-tragedia-deja-mas-de-100-muertos

Corradini, L. (2015b, 5 de septiembre). En Alemania, el sufrimiento de los refugiados se da cita con la solidaridad. En lanacion.com. Recuperado el 7 de septiembre de 2015 de http:/ / www.lanacion.com.ar/1825324-en-alemania-el-sufrimiento-de-los-refugiados-se-da-cita-con-la-solidaridad

Edwards, A. (2015, 29 de agosto). No es lo mismo migrante que refugiado. En lanacion.com. Recuperado el 1 de septiembre de 2015 de http://www.lanacion.com.ar/1823222-no-es-lo-mismo-migrante-que-refugiado

Fischer-Lichte, E. (2011). Estética de lo performativo. Madrid: Abada editores.

Frisby, D. (1992). Fragmentos de la modernidad: teorías de la modernidad en la obra de Simmel, Kracauer y Benjamin. Madrid: Visor.

Gigena, D. (2015, 3 de agosto). Entrevista a Sergio Chejfec: "Escribir es el resultado de una operación de la voluntad”. En lanacion.com. Recuperado el 4 de agosto de 2015de http: / / www.lanacion.com.ar/1815713-sergio-chejfec-escribir-es-el-resultado-de-una-operacion-de-la-voluntad

La Vanguardia (2015, 20 de junio). Piden un cambio de las políticas de refugiados en la Unión Europea. Recuperado el 25 de junio de 2015 de http://www.lavanguardia.com/vida/20150620/54432941731/ piden-un-cambio-de-las-politicas-de-refugiados-en-la-union-europea.html

lanacion.com (2005a, 5 de septiembre). Fin de la reunión de la UE: “Terminó el juego de echarse culpas y llegó el momento de tomar medidas". Recuperado el 7 de septiembre de 2015 de http://www. lanacion.com.ar/1825419-fin-de-la-reunion-de-la-ue-termino-eljuego-de-echarse-culpas-y-llego-el-momento-de-tomar-medidas 
lanacion.com (2005b, 5 de septiembre). Los refugiados se rebelan contra la UE y presionan por una solución. Recuperado el 7 de septiembre de 2015 de http:/ / www.lanacion.com.ar/1825344-los-refugiadosse-rebelan-contra-la-ue-y-presionan-por-una-solucion

lanacion.com (2005c, 5 de septiembre). Un gesto en medio del drama: en Alemania esperan a los refugiados con peluches. Recuperado el 7 de septiembre de 2015 de http://www.lanacion.com.ar/1825426-un-gesto-en-medio-del-drama-en-alemania-esperan-a-los-refugiados-con-peluches

Mateos, A. (2015, 3 de septiembre). La imagen de Aylan Kurdi agita la conciencia de Europa. En ABC.es. Recuperado el 5 de septiembre de 2015 de http://www.abc.es/internacional/20150903/abci-ninomuerto-turquia-inmigrante-201509030125.html

Mauss, M. (1971). Ensayo sobre el don: forma y razón del intercambio en las sociedades arcaicas. Madrid: Tecnos.

Melman, C. (2005). El hombre sin gravedad: gozar a cualquier precio. Rosario, Argentina: Universidad Nacional del Rosario.

Rancière, J. (2009). El reparto de lo sensible: estética y política. Santiago de Chile: LOM Ediciones.

Tomino, P. (2015, 25 de agosto). Wifi gratis: la villa 1-11-14 es donde más se lo utiliza. En lanacion.com. Recuperado el 27 de agosto de 2015 de http://www.lanacion.com.ar/1822006-wi-fi-gratis-la-villa1-11-14-es-donde-mas-se-lo-utiliza

Valdettaro, S. (2012). Fuego, revolución, tecnologías: la masa te pasa a buscar. En M. Carlón y F. Neto, La política de los cibernautas: nuevas formas de participación. Buenos Aires: La Crujía. 
Venturini, F. (2015, 5 de septiembre). La hora de salvar inmigrantes y la unidad de Europa. En lanacion.com. Recuperado el 7 de septiembre de 2015 de http://www.lanacion.com.ar/1825327-la-horade-salvar-inmigrantes-y-la-unidad-de-europa

Verón, E. (2013). La semiosis social 2: ideas, momentos, interpretantes. Buenos Aires: Paidós. 
